\section{RELATIVE CHARACTERIZATION OF IMMOBILIZED BETA-GLUCOSIDASE ON CALCIUM-ALGINATE AND ACID FUNCTIONALIZED MULTIWALLED CARBON NANOTUBES}

\author{
Ahmad T. Jameel*, Kauthar Y. Maalim, Faridah Yusof \\ Biotechnology Engineering Department, Kulliyyah of Engineering \\ International Islamic University Malaysia, Gombak, 50728 Kuala \\ Lumpur, Malaysia
}

Article history

Received

11 November 2018

Received in revised form

16 January 2019

Accepted

23 January 2019

Published online

18 April 2019

\section{*Corresponding author} atjameel@iium.edu.my
Graphical abstract

W

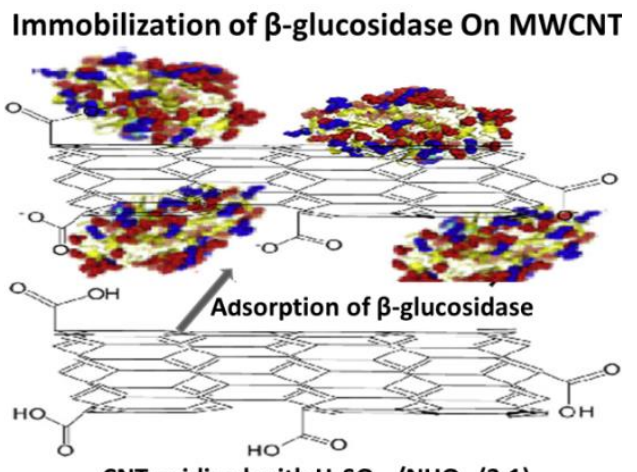

CNT oxidized with $\mathrm{H}_{2} \mathrm{SO}_{4} / \mathrm{NHO}_{3}$ (3:1)

\begin{abstract}
Natural polymeric gel such as alginate and carrageenan, and carbon nanomaterials, especially MWCNT and graphene are gaining increasing popularity as immobilization support owing to their biocompatibility. Thus, this study attempts to make a relative characterization of the immobilized $\beta$ glucosidase on alginate and multiwalled carbon nanotubes (MWCNT) to assess their relative merits as biocatalyst. Acid functionalization of MWCNT lead to the formation of carboxyl groups at the MWCNT surface which seemed to have role in the stable attachment of the enzyme on the MWCNT surface. The effectiveness of the immobilized enzyme was evaluated using hydrolysis of $\mathrm{p}$ nitrophenyl- $\beta$-D-glucopyranoside to $\mathrm{p}$-nitrophenol. The optimum immobilization conditions were found to be $17 \mathrm{mg} \mathrm{MWCNT}$ and $4 \mathrm{~h}$ incubation time for MWCNT, and $3.5 \mathrm{wt} \%$ sodium alginate solution and $2 \mathrm{~h}$ incubation time for the $\mathrm{Ca}$ alginate beads. The immobilization yield on MWCNT was found to be $96 \%$ and that for the Ca-alginate beads was $86 \%$. The residual activity of the enzyme at the third cycle of subsequent reuse was $85 \%$ for the enzyme-MWCNT and almost $50 \%$ for the enzyme-alginate beads. Both, Ca-alginate and MWCNT immobilized enzyme were found to follow Michaelis-Menten kinetics. The kinetic data were best represented by the Langmuir plot. The kinetic constants $V_{\max }$ and $K_{m}$ for the MWCNT immobilized enzyme were obtained as $1.324 \mathrm{mM} / \mathrm{min}$ and $0.801 \mathrm{mM}$, respectively, while for the alginate immobilized enzyme, the constants predicted were $1.240 \mathrm{mM} / \mathrm{min}$ and $0.524 \mathrm{mM}$, respectively. Thus MWCNT immobilized $\beta$ glucosidase exhibited greater stability in terms of activity and reusability compared to Ca-alginate beads.
\end{abstract}

Keywords: $\beta$-glucosidase, MWCNT, Ca-alginate, immobilization, kinetics

\begin{abstract}
Abstrak
Gel polimer semulajadi seperti alginat dan carrageenan, dan nanomaterials karbon, terutamanya MWCNT dan graphene semakin meningkat populariti sebagai sokongan imobilisasi enzim kerana biokompatibiliti mereka. Oleh itu, kajian ini cuba membuat perbandingan ciri-ciri relatif antara $\beta$-glucosidase pada alginate dan nanotube karbon (MWCNT) untuk menilai merit mereka sebagai biokatalist. Fungsionalisasi asid pada MWCNT membawa kepada pembentukan kumpulan karboksil di permukaan MWCNT yang mempunyai peranan dalam pemasangan enzim yang stabil pada permukaannya. Keberkesanan imobilisasi enzim dinilai menggunakan hidrolisis $p$-nitrophenyl- $\beta-D$ glucopyranoside kepada p-nitrophenol. Imobilisasi optimum untuk MWCNT ialah menggunakan $17 \mathrm{mg}$ MWCNT dan masa inkubasi $4 \mathrm{~h}$ dan untuk Ca-alginate
\end{abstract}


ialah menggunakan 3.5\% larutan natrium alginat dan masa inkubasi $2 \mathrm{~h}$. Hasil menunjukkan bahawa imobilisasi enzim pada MWCNT memberi keaktifan $96 \%$ dan $86 \%$ untuk manik Ca-alginate. Apabila digunakan semula, pada kitaran ketiga penggunaan, enzim-MWCNT menghasilkan keaktifan $85 \%$ dan dan hampir 50\% untuk manik enzim-Ca-alginat. Kedua-dua sistem enzim, enzimMWCNT dan enzim-Ca-alginate didapati mengikuti kinetik Michaelis-Menten. Data kinetik yang terbaik diwakili oleh plot Langmuir. Pemalar kinetic, $V_{\max }$ dan $\mathrm{K}_{\mathrm{m}}$ untuk enzim-MWCNT ialah masing-masing sebagai $1.324 \mathrm{mM} / \mathrm{min}$ dan 0.801 $\mathrm{mM}$, manakala bagi enzim-Ca-alginat ialah $1.240 \mathrm{mM} / \mathrm{min}$ dan $0.524 \mathrm{mM}$. Oleh itu, $\beta$-glucosidase-MWCNT memaparkan kestabilan yang lebih besar dari segi aktiviti dan kebolehbasaian berbanding dengan $\beta$-glucosidase-Ca-alginat.

Kata kunci: $\beta$-glucosidase, MWCNT, Ca-alginat, immobilisasi, kinetik

(C) 2019 Penerbit UTM Press. All rights reserved

\subsection{INTRODUCTION}

$\beta$-Glucosidase has been widely used as an effective catalyst for hydrolysis of various glycosides. However, free $\beta$-glucosidase is relatively unstable as it can be easily denatured at extreme conditions of $\mathrm{pH}$ and temperature, and is expensive and difficult to recover from the reactor effluent [1-4]. The immobilization of enzymes on nanomaterials such as multiwalled carbon nanotubes (MWCNT) and on/in a gel matrix support such as sodium alginate increases the thermal stability and efficiency of the enzyme besides ease of separation from the reaction mixture. The operational stability of enzymes has been largely improved over the years using immobilization on support material resulting in lower production cost and improved process and product controls [1-8]. Besides enhanced stability, ease of separation of the enzyme from the product mixture facilitates its multiple reuse and prevents protein contamination of the final product. Different support materials are being used for immobilization; these include nanopolymer, chitosan, Ca-alginate and $\mathrm{k}$-carrageenan porous matrices [9]. Some of the support materials have to be functionalized in order to create functional groups on the surface of the material which in turn enhances the enzyme attachment [1014]. At times, enzyme crosslinking with bi-functional reagents like glutaraldehyde (GA) and polyethyleneimine (PEI) followed by entrapment in natural polymers can provide greater stability to enzyme attachment on/in the support [4]. The extent of interaction of the enzymes with the substrate determines the efficiency and specificity of the enzyme. Three factors important for efficient immobilization of an enzyme are: (1) nature of the enzyme; (2) nature of the support material, and (3) immobilization technique.

$\beta$-Glucosidase has been immobilized on different supports, such as alginate, polyacrylamide gel, silica gel, magnetic chitosan microspheres, and $\mathrm{K}$ carrageenan matrix [1, 4, 9]. Lately, immobilization on nano-materials has been gaining importance owing to greater stability and high activity of enzymes achievable on such support materials $[3,9,10,12-15$, 17].

Roy et al. [18] studied the immobilization of $\beta$ glucosidase from Myceliophthora thermophile D-14 by covalent bonding to $\mathrm{CNBr}$-activated sepharose and entrapment within crosslinked polyacrylamide gels. Significant improvement in operational as well as storage stability was observed for the immobilized enzyme. In another study, $\beta$-glucosidase from almond was immobilized on MWCNTs by adsorption with an enzyme loading of $630 \mathrm{mg} / \mathrm{mg}$ support and catalytic activity above $400 \mathrm{U} / \mathrm{g}$ of MWCNT was achieved for the hydrolysis of 4-nitrophenyl- $\beta$-D-glucopyranoside (p-NPG) [17]. Covalent immobilization of Kluyveromyces lactis $\beta$-galactosidase on glutaraldehyde modified MWCNTs demonstrated enhanced stability compared to free enzyme in solution [1]. Immobilization of $\beta$-D-glucosidase in alginate gel matrix by entrapment was shown to retain only about $20 \%$ of original activity possibly due to the effect of mass transfer resistance to substrate and product through the alginate network [2]. A novel hybrid matrix of glutaraldehyde (GA) cross linked kappa-carrageenan and further modified using polyelectrolyte (PEI) followed by a mediator (GA) to bind $\beta$-glucosidase via covalent bond was developed by Tan and Lee [4]. This hybrid matrix support exhibits low enzyme leakage, and has high immobilization efficiency, enzyme activity, and reusability. Immobilized enzyme showed higher tolerance to a broader range of $\mathrm{pH}$ and higher reaction temperature of up to $60^{\circ} \mathrm{C}$ compared to soluble enzyme [4].

Several work had reported on the use of polymer matrix as well as carbon nanotubes as support material for immobilization of lipases $[5,7,8,10,12-16$, 19-27]. Tumkur et al. [7] used two novel polymeric matrices for immobilization of lipase using covalent binding and entrapment methods. Optimum $\mathrm{pH}$ and temperature as well as Michaelis constants were obtained for free and immobilized lipase. Storage and thermal stability of enzyme was reported to 
increase as a result of immobilization [7]. The alginate beads coated with chitosan and silicate enhanced operational stability and reduced enzyme leakage [16]. In one of the studies, lipase was immobilized by entrapment in agarose, alginate, and chitosan for a comparative evaluation of enzyme loading, leaching and activity. A higher lipase activity in chitosan beads compared to that in alginate beads could merit chitosan worthy of further study as an enzyme immobilization support [19]. In yet another study, lipase from Candida rugosa was immobilized in alginate beads for application in palm oil hydrolysis in lecithin/isooctane system [20]. Enhanced thermal stability and high reusability was achieved for the Jack bean urease immobilized in chitosan-alginate polyelectrolyte complexes as reported by Filiz Cara et al. [8]. In a relatively recent work, Abdullah and Ravindra) [5] carried out immobilization of lipase from Burkholderia cepacia by first cross linking with glutaraldehyde followed by entrapment into hybrid matrix of equal amounts of alginate and $\mathrm{k}$ carrageenan natural polymers extracted from seaweeds. Higher thermal and storage stability, reduced enzyme leakage and a higher activity yield was obtained using this method of enzyme immobilization. In another work, Dizge et al. [25] successfully used hydrophobic copolymer to covalently immobilize microbial lipase by means of polyglutaraldehyde for use as a biocatalyst in the transesterification reaction. Ortega et al. [26] studied immobilization of $\beta$-glucosidase from Aspergillus niger, by entrapment in alginate and polyacrylamide gels. They found that higher activity (65\%) was retained in alginate gel compared to polyacrylamide gel. Changes in kinetic parameters and pH-activity of the immobilized enzyme compared to soluble enzyme were also reported [26]. In a later work, Su et al. [27] effectively immobilized $\beta$-glucosidase in sodium alginate by crosslinking-entrapment-crosslinking method; and the properties of free and immobilized enzyme were compared. Immobilized $\beta$-glucosidase was used to treat tea beverage to hydrolyze the glycosidic aroma precursors effectively to be used for aroma-increasing in tea beverage industry [27]. In a recent study, Coutinho et al. [28] showed that $\beta$ glucosidase could be efficiently immobilized on hydroxyapatite nanoparticles by adsorption. The immobilization resulted in high immobilization yields and recovered activities of up to $90 \%$, over wide ranges of $\mathrm{pHs}$ and ionic strengths. The immobilized $\beta$ glucosidase retained about $70 \%$ of its initial activity after 10 cycles of reuse, demonstrating increased operational stability of immobilized enzyme [28]. In another recent research, Han et al. [29] demonstrated that immobilized cellulase on composite magnetic nanomaterial synthesized from graphene and magnetic $\mathrm{Fe}_{3} \mathrm{O}_{4}$ exhibited enhanced thermostability, storage stability, and reusability than soluble enzyme. They obtained up to $60 \%$ maximum residual stability after 30 days storage at room temperature. Immobilized cellulase after eight times reuse retained up to $45 \%$ of initial activity [29].
The lipase was immobilized by Li et al. [12] using adsorption on amino-cyclodextrin functionalized carbon nanotubes for enzymatic catalysis at the ionic liquid-organic solvent interface resulting into increased catalytic activity compared to soluble enzyme. Enhanced stability was achieved for the cellulase enzyme immobilized onto acid functionalized MWCNTs [13]. Prlainovic et al. [14] studied the influence of two different immobilization methods on enzyme loading and activity of Candida rugosa lipase immobilized on oxidized MWCNTs. In another study, Candida rugose lipase was successfully adsorbed on raw MWCNT [3]. Yet in another work, Thermomyces lanuginosu lipase was successfully immobilized on amino-functionalized MWCNs and the structure and function of the immobilized enzyme was characterized [15]. In a recent study, covalently functionalized MWCNTs were investigated as support for lipase catalyzed stereo selective synthesis of Solketal n-butyrate [4].

In light of the above cited literature, it is apparent that natural polymeric gel matrix supports had been widely used for immobilization of enzyme primarily due to their biocompatibility and cost effectiveness. Carbon nanomaterials, especially MWCNT and grapheme, on the other hand, have been gaining increasing popularity as enzyme support for biocatalyst design due to their special characteristics. This study has attempted to present a relative characterization of $\beta$-glucosidase enzyme immobilized on alginate and MWCNT, to assess the relative merits of these two popularly employed support material for enzyme immobilization. We have tried to find the optimum conditions for maximum enzyme loading with respect to mass ratio of enzyme to MWCNT support, and the curing time for the immobilization of $\beta$-glucosidase on acid functionalized MWCNT. For immobilization using alginate gel, the sodium alginate concentration $(\mathrm{w} / \mathrm{v})$ to enzyme mass ratio and curing time were considered. First, statistical optimization was carried out followed by experimental verification. The optimally synthesized biocatalysts were further studied for activity yield. Next, enzyme residual activity of optimally synthesized biocatalyst for three subsequent reuses in the enzymatic hydrolysis of PNPG was evaluated. Finally, the kinetic constants were evaluated using linearized Michaelis-Menten plots, and the best fit (maximum $\mathrm{R}^{2}$ value) was obtained using the Langmuir plot.

\subsection{METHODOLOGY}

\subsection{Materials and Reagents}

Multiwalled carbon nanotubes, $\beta$-glucosidase enzyme from sweet almond and $p$-nitrophenyl- $\beta-D$ glucopyranoside (pNPG) were obtained from SigmaAldrich and sodium alginate from Fisher Chemical. Nitric acid, sulphuric acid, and other chemicals used were standard laboratory grade reagents. 
Multiwalled carbon nanotube from Sigma Aldrich (Product No. 773840) specifications is: Purity: $>98 \%$ carbon basis by $\mathrm{X}$-ray diffraction;

Outer diameter: $10 \mathrm{~nm} \pm 1 \mathrm{~nm}$; Inner diameter: 4.5 $\mathrm{nm} \pm 0.5 \mathrm{~nm}$; Length: $3-\sim 6 \mu \mathrm{m}$, TEM; BET surface area: $216 \mathrm{~m}^{2} / \mathrm{g}$; Pore volume: $0.8 \mathrm{~cm}^{3} / \mathrm{g}$; Aspect ratio > 350-550 determined by AFM; Bulk density: 0.068 $\mathrm{g} / \mathrm{cm}^{3}$.

\subsection{Immobilization of $\beta$-glucosidase on MWCNT}

Experiments for the preparation of immobilized $\beta$ glucosidase on MWCNTs were carried out in two phases, viz., surface functionalization of the MWCNT, and optimization of the immobilization conditions.

\subsubsection{Surface Functionalization of MWCNT}

MWCNT was functionalized using concentrated sulphuric (95\%) and nitric $(65 \%)$ acids in the ratio of 3:1 following the method used by Mubarak et al. [13]. MWCNT $(100 \mathrm{mg})$ was added to a mixture of concentrated acid in a tube. The mixture was kept in ultrasonic bath at $60{ }^{\circ} \mathrm{C}$ for $3.5 \mathrm{~h}$ [13]. Next, the mixture was diluted with distilled water and then vacuum filtered through a $0.2 \mathrm{\mu m}$ pore polytetrafluoro-ethylene (PTFE) membrane which was treated with ethanol before being used. The oxidised MWCNT was dried in an oven at $80{ }^{\circ} \mathrm{C}$ for $5 \mathrm{~h}$. The surface of functionalized-MWCNT was characterized using the Fourier Tansform Infrared Spectroscopy (FTIR) and Scanning Electron Microscopy (SEM), and then stored for further usage.

\subsubsection{Adsorption of $\beta$-glucosidase on Functionalized MWCNT}

Acetate buffer in $20 \mathrm{~mL}$ volume having $0.1 \mathrm{M}$ concentration at $\mathrm{pH} 5.0$ was added to $4 \mathrm{mg}$ of functionalized-MWCNT. The mixture was sonicated for 30 minutes. Enzyme solution was prepared by adding $1 \mathrm{mg} \beta$-glucosidase in $1 \mathrm{~mL}$ of $0.1 \mathrm{M}$ sodium acetate buffer at $\mathrm{pH} 5$. The solution of MWCNT was mixed with $0.5 \mathrm{~mL}$ of enzyme solution and the mixture was put in a shaker at $37^{\circ} \mathrm{C}$ at $200 \mathrm{rpm}$ for $2 \mathrm{~h}$. Then the solution was vacuum filtered to separate the enzyme immobilized-MWCNT from the unbound enzyme residual solution. The enzyme activity was determined for both residual and immobilized enzyme [1, 10, 12, 13, 17]. The immobilization condition was optimized with respect to immobilization time and mass of MWCNT/mass of enzyme using statistical design of experiments (DOE) employing Design Expert 6.0.8 software.

\subsection{Entrapment of $\beta$-glucosidase on $\mathrm{Ca}$-alginate Beads}

Sodium alginate with concentration of $3 \%(\mathrm{w} / \mathrm{v})$ and $\mathrm{CaCl}_{2}(0.1 \mathrm{M})$ solutions were prepared separately by dissolving them in $0.1 \mathrm{M}$ sodium acetate buffer at $\mathrm{pH}$
5. One $\mathrm{mL}$ of enzyme solution (1 $\mathrm{mg} \beta$-glucosidase dissolved in $1 \mathrm{~mL}$ of $0.1 \mathrm{M}$ sodium acetate buffer at $\mathrm{pH}$ 5) was added to $10 \mathrm{~mL}$ sodium alginate solution and gently stirred for 30 minutes. The homogeneous solution was then dripped drop wise in a calcium chloride solution using pipette with a $3 \mathrm{~mm}$ diameter tip. The beads were allowed to harden for 30 minutes and washed twice with buffer and stored at $4{ }^{\circ} \mathrm{C}$ for later use. The washing solutions were collected and used for the lost enzyme studies [2, 16, 18, 19]. The immobilized calcium-alginate beads were optimized with respect to immobilization time and sodium alginate concentration (w/v) using Design Expert 6.0.8. To optimize immobilization conditions, immobilization time was varied as $2 \mathrm{~h}, 3.5 \mathrm{~h}$ and $5 \mathrm{~h}$, and sodium alginate concentration $(\mathrm{g} / \mathrm{mL})$ varied as $2,3.5$ and 5 according to the experimental design from the Design Expert 6.0.8 software [30].

2.4 Determination of free and immobilized $\beta$ glucosidase activity

A spectrophotometric assay was used to determine the hydrolytic activity of free and immobilized enzyme on the hydrolysis of $10 \mathrm{mM}$ p-nitrophenyl- $\beta-D$ glucopyranoside (pNPG) as the substrate. The immobilized enzyme activity was determined as follows.

The substrate, pNPG (1 mL) was mixed with solid support (MWCNT and Ca-alginate beads) containing immobilized enzyme and $1 \mathrm{~mL}$ of $0.1 \mathrm{M}$ sodium acetate buffer at $\mathrm{pH} 5$ was added to this mixture. The mixture was then incubated at $50{ }^{\circ} \mathrm{C}$ for 25 minutes. The reaction was stopped by adding $1 \mathrm{~mL}$ of $1.0 \mathrm{M}$ sodium carbonate to the reaction mixture. The amount of p-nitrophenol (pNP) liberated as a result of the reaction was measured by reading absorbance using a spectrophotometer at $410 \mathrm{~nm}$. The concentration of pNP was calculated from the standard curve which was finally used to calculate enzyme activity $[20,21]$. One unit of enzyme activity was defined as the amount of enzyme required to produce $1 \mathrm{\mu mol}$ of $\mathrm{p}$-nitrophenol (pNP) from hydrolysis of the substrate, pNPG per minute under the given assay conditions [6].

The free enzyme assay was prepared by dissolving $1 \mathrm{mg} \beta$-glucosidase in $1 \mathrm{~mL}$ of $0.1 \mathrm{M}$ sodium acetate buffer at $\mathrm{pH} 5$ and the solution was added to $1 \mathrm{~mL}$ of PNPG substrate. The mixture was incubated in water bath at $50{ }^{\circ} \mathrm{C}$ for 25 minutes. Following this procedure, free enzyme activity was calculated.

\subsection{Immobilization Yield}

Immobilization yield (also termed as activity yield) can be defined to represent the extent of enzyme immobilization in terms of its activity; this compares the activity of immobilized enzyme to the activity of free enzyme [5, 17]. Immobilization yield is expressed by the following equation $[5,16]$ : 
Immobilization yield $(\%)=\left(\frac{A_{f}-A_{r w}}{A_{f}}\right) \times 100$

where $A_{f}$ is the specific activity of free enzyme in the stock solution ( $\mu \mathrm{mol} / \mathrm{min} . \mathrm{mg}$ protein), and $A_{r w}$, is the specific activity of enzyme in the residual and wash solutions combined ( $\mu \mathrm{mol} / \mathrm{min} . \mathrm{mg}$ protein).

Spectrophotometric assay was used to determine hydrolytic activity of the native enzyme stock solution and that of the enzyme in the washout and residual solutions mixed together, for the hydrolysis of $10 \mathrm{mM}$ p-nitrophenyl- $\beta$-D-glucopyranoside (pNPG) as described in Section 2.4. The difference of the two activities gives the activity of the immobilized enzyme. Specific activity is the activity per unit mass of the enzyme. Since initially $1 \mathrm{mg}$ enzyme was used in the activity assay, the measured activity corresponds to the specific activity.

\subsection{RESULTS AND DISCUSSION}

\subsection{Fourier Transform Infrared Spectroscopy (FTIR)}

Fourier Transform Infrared Spectroscopy is one of the methods used for surface characterization. This helps in identifying the functional groups present on the surface. MWCNT were mixed with potassium bromide $(\mathrm{KBr})$ before characterization [13, 14]. This was done in order to enhance the transmission process since the black coloured MWCNT tend to give strong absorbance which makes it difficult to distinguish them from the background noise.

Figure 1 shows the FTIR spectra for pristine (a) and acid functionalized MWCNT (b), plotted as absorbance vs. wavenumber $\left(\mathrm{cm}^{-1}\right)$. It can be seen in Figure 1 that there was no functional group present on the pristine MWCNT surface corresponding to spectrum (a), since no clear sharp peaks were formed. Similar spectra, almost flat for wavelengths in the range $4000 \mathrm{~cm}^{-1}-1000 \mathrm{~cm}^{-1}$ was reported in the literature for raw MWCTN [22]. The FTIR image for the above sample of MWCNT after functionalization is shown in the spectrum labelled (b) with several prominent peaks. The Infra-red absorptions in the wavelength range $1800-1600 \mathrm{~cm}^{-1}$ indicate the presence of carboxylic acid molecules on the surface. The FTIR spectra shown in Figure $1 \mathrm{~b}$ depict several peaks in this range which reveal that carboxyl groups, $(\mathrm{C}=\mathrm{O})$ ) (corresponding to IR absorption 1797 $\mathrm{cm}^{-1}$ and $1625 \mathrm{~cm}^{-1}$ in the graph) were present on the surface. These peaks in the o-MWCNT spectrum arise from the stretching vibrations of $-\mathrm{OH}$ and $\mathrm{C}=\mathrm{O}$ bonds from the carboxylic groups, respectively [14]. The peak at $1412 \mathrm{~cm}^{-1}$ is likely from sulphate groups which is a consequence of the MWCNT surface oxidation [14]. The additional peaks at 1294 $\mathrm{cm}^{-1}$ and $1134 \mathrm{~cm}^{-1}$ may be due to stretching vibrations of $-\mathrm{C}-\mathrm{O}$ bonds and the successful rehybridization of carbon from $\mathrm{sp}^{2}$ to $\mathrm{sp}^{3}$ which further confirms the oxidation of MWCNT [14]. Similar wavelengths for carboxyl groups have been reported in the literature for acid functionalized MWCNT $[13,14]$.

3.2 Effect of Immobilization on the Surface Morphology of Functionalized MWCNT

The surface morphologies of the functionalized MWCNT before and after immobilization were obtained using scanning electron microscopy (SEM) (instrument model JSM-5600). Magnification values of 100 and 2000 were used in order to compare the differences in the surface morphologies between non-immobilized and immobilized MWCNT as shown in Figures 2 and 3.

The MWCNT were seen to have an approximate length of $10 \mathrm{\mu m}$. Figures $2(\mathrm{a})$ and $3(\mathrm{a})$ show the functionalized MWCNT where MWCNT were seen clumped together. Figure $3(a)$ clearly shows the typical dimension of the MWCNT aggregates of length about $8 \mu \mathrm{m}$ and width 4-5 $\mu \mathrm{m}$. Figures $2(\mathrm{~b})$ and $3(\mathrm{~b})$ show the surface of MWCNT with immobilized enzymes which appear relatively smooth in the image as if the enzyme molecules had filled the interstitial spaces with a fine surface coating of enzyme layer. Qualitative features of images in Figures 2 and 3 are in close conformity to FESEM images in Mubarak et al. [13). The $\beta$-glucosidase immobilized MWCNT images in Figures $2 b$ and $3 b$ are qualitatively similar to SEM images for covalent lipase immobilization on MWCNT-OH matrix in Zniszczol et al. [24].

3.3 Optimum Parameters for Immobilization of $\beta$ glucosidase Enzyme on MWCT and Calcium Alginate Beads

Statistical analysis using Design Expert 6.0.8 software was used to arrive at the optimum conditions with respect to immobilization time, and mass ratio of MWCNT to enzyme (protein) for MWCNT as support material. For $\beta$-glucosidase immobilization on $\mathrm{Ca}$ alginate beads, curing time and weight percent sodium alginate was chosen for optimization.

Since only two parameters were considered, response surface method with central composite design was used for the design of experiments (DOE). Thirteen experimental runs were performed for each of the support. Based on the responses, an analysis was performed and the results obtained were as follows. 


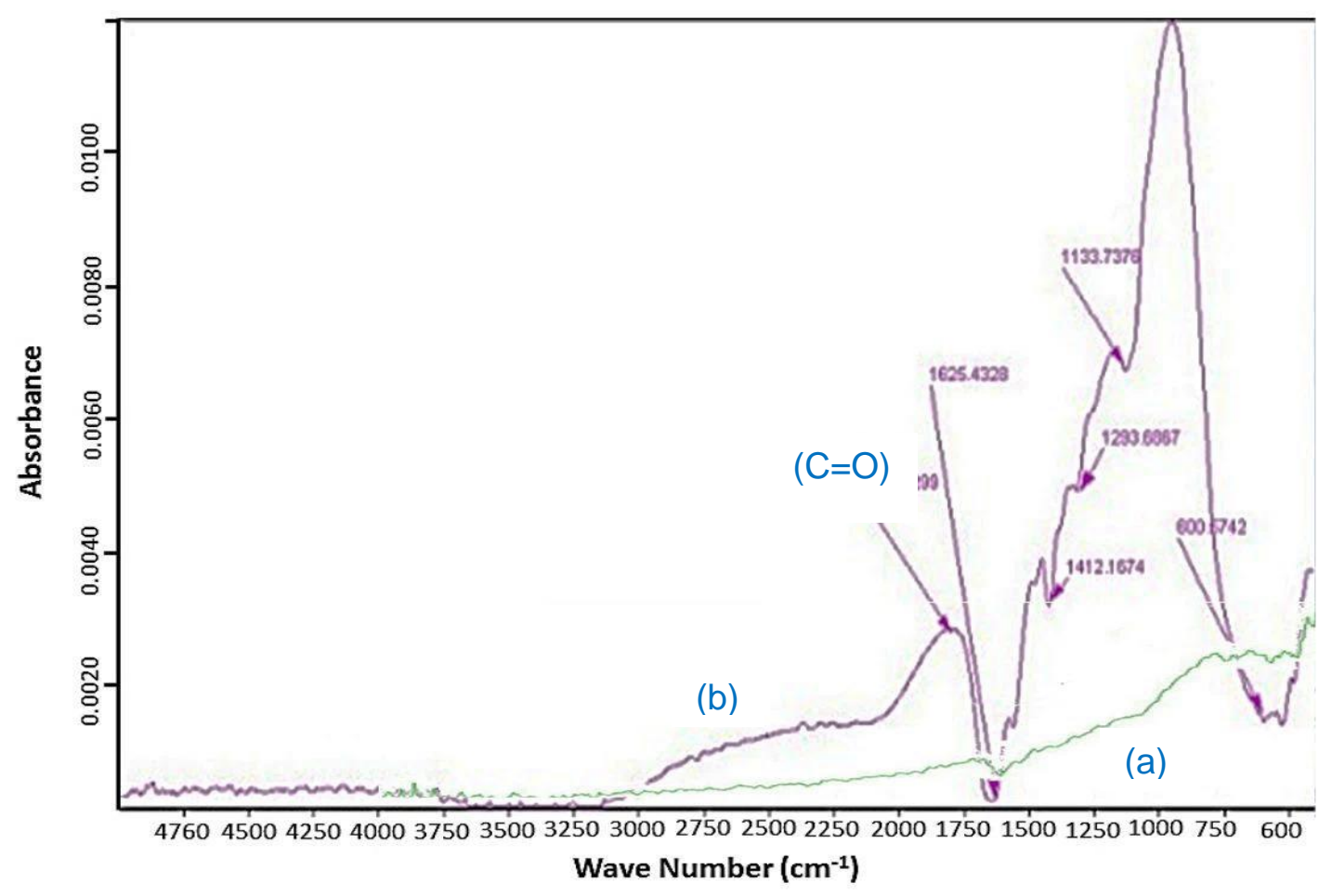

Figure 1 FTIR spectra: (a) for pristine MWCNT; (b) for acid functionalized MWCNT

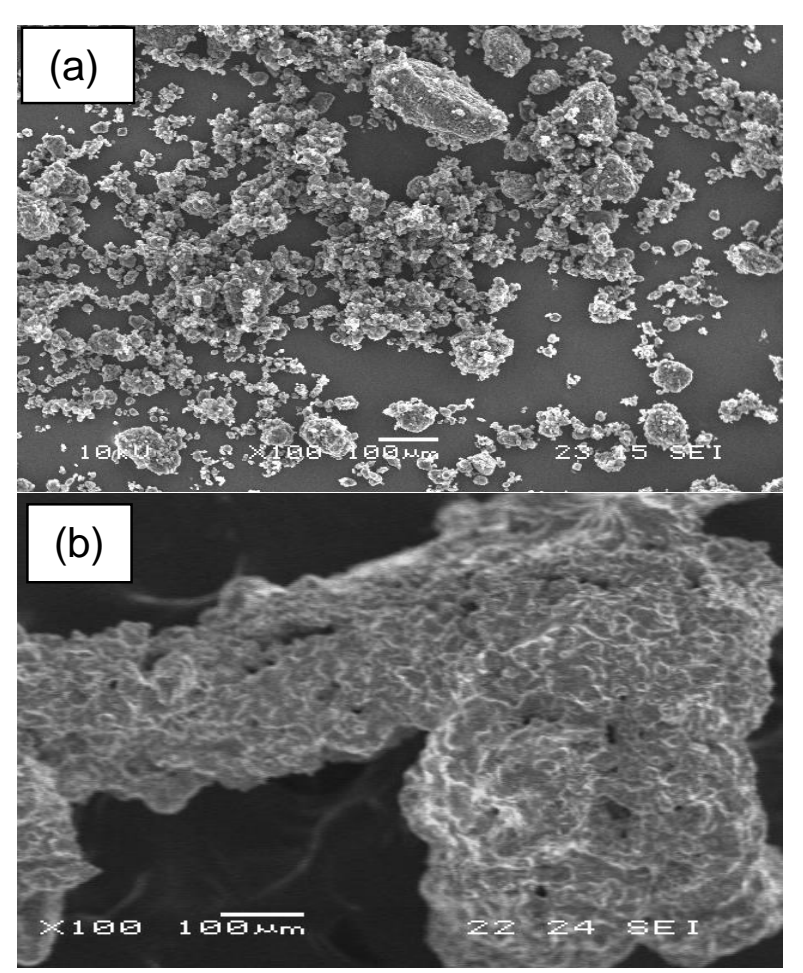

Figure 2 SEM micrographs of functionalised MWCNT X 100 magnification: (a) Before $\beta$-glucosidase immobilization; (b) after $\beta$-glucosidase immobilization
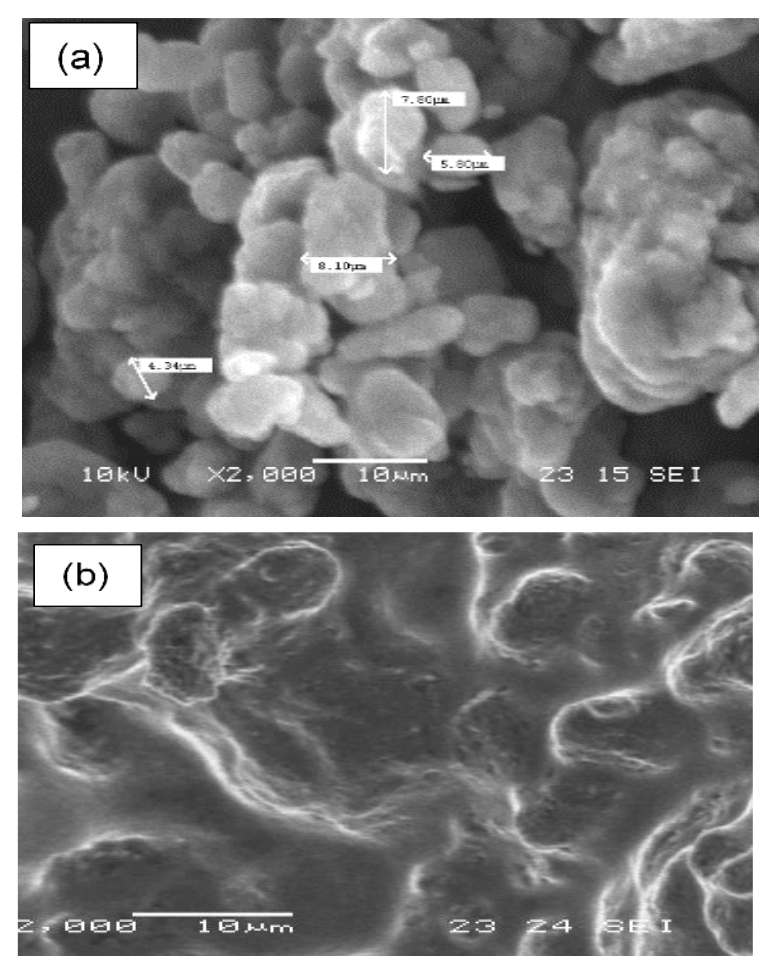

Figure 3 SEM micrographs of functionalised MWCNT X 2000 magnification: (a) Before $\beta$-glucosidase immobilization; (b) after $\beta$-glucosidase immobilization 
In the case of MWCNT as support, enzyme loading increased with immobilization time and became saturated with increase in time [24]. The mass of MWCNT was increased gradually keeping the mass of enzyme $(1 \mathrm{mg})$ constant. Maximum loading of the enzyme (96\%) was obtained at $4 \mathrm{~h}$ and $17 \mathrm{mg}$ of MWCNT. In the case of immobilization in calcium alginate beads, enzyme loading increased with weight percent of sodium alginate for a fixed mass (1 $\mathrm{mg}$ ) of enzyme, attaining a maximum and then decreasing. Immobilization time did not cast significant effect on the enzyme loading [4, 5, and 16]. Maximum loading of the enzyme (86\%) was obtained at $2 \mathrm{~h}$ and $3.5 \mathrm{wt} \%$ of sodium alginate solution. Three-D plots from DOE are omitted for the sake of compactness. Details of methodology and results of statistical design may be found elsewhere [30].

\subsection{Effectiveness of the Enzyme Immobilized on MWCNT and in Alginate Gel}

Immobilization yield was measured under optimum conditions to determine the effectiveness of the enzyme immobilized on MWCNT and Ca-alginate beads. Immobilization yield was calculated using Equation (1).

Immobilization yield for MWCNT and Ca-alginate beads are compared in Figure 4. The immobilization yield of MWCNT was found to be $96 \%$ and that of CaAlginate beads was $86 \%$. This shows a higher efficiency of immobilization of the enzyme on MWCNT support compared to Ca-alginate beads [16]. This result is in agreement Feng and Ji's [10] observation that nanomaterials serve as excellent support materials for enzyme immobilization because they offer the ideal characteristics for balancing factors that determine the efficiency of biocatalysts, surface area, mass transfer resistance and effective enzyme loading.

Figure 5 shows the percentage of residual activity for three subsequent uses of the immobilized catalyst. It was observed that MWCNT retained more activity on subsequent use compared to the Ca-alginate beads. Residual activity for $\beta$-glucosidase enzyme immobilized on MWCNT was found to be $87.46 \%$ and $85.55 \%$ for the second and third cycles respectively, while the corresponding activities for the Ca-alginate beads were found to be $82.64 \%$ and $49.34 \%$ [16]. Residual activities of the MWCNT supported enzyme are comparable to those reported by Shakeel et al. [1] for $\beta$-galactosidase immobilized on glutraldehyde modified MWCNT, and Mubarak et al. [13] for cellulase on acid oxidized MWCNT]. Ca-alginate beads have been observed to lose almost $50 \%$ of the activity in the third run. Contrary to this, Abdullah and Ravindra [5] reported $90 \%$ activity recovery after the third cycle of use and almost $75 \%$ relative activity after 10 cycles of reuse. A high activity recovery upon multiple use in this case may be attributed to crosslinking prior to entrapment of the enzyme in a hybrid matrix of alginate and carrageenan [5]. On the other hand, a residual activity of $17.85 \%$ after 4 reuses of immobilized $\beta$-glucosidase in alginate gel beads has been reported by Keerti et al. [21]. A low activity retention (50\%) after the third cycle of reuse in our case may be due to enzyme leakage and also deactivation of $\beta$-glucosidase during the reuse process [5]. Coating the surface of calcium alginate beads with chitosan or silicate is believed to prevent enzyme leaking and thus retain the activity [16]. Therefore our results on reusability reveal the fact that MWCNT provide stronger binding of the enzyme possibly due to surface functionalization leading to higher structural stability of the immobilized $\beta$ glucosidase owing to covalent bonding between the enzyme molecule and the functional groups.

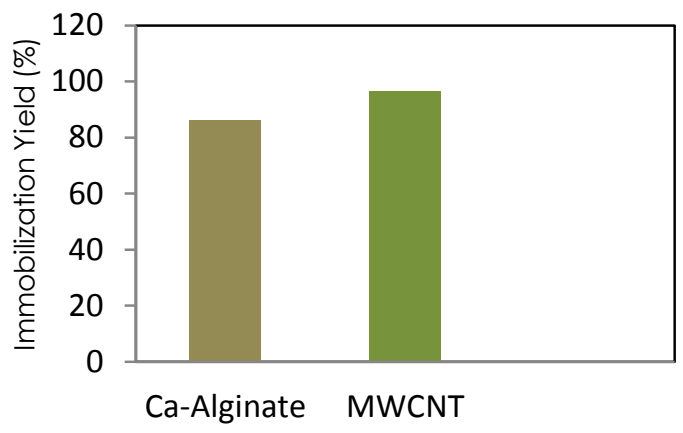

Figure 4 Comparison of immobilization yield for MWCNT and Ca-Alginate beads as immobilization support

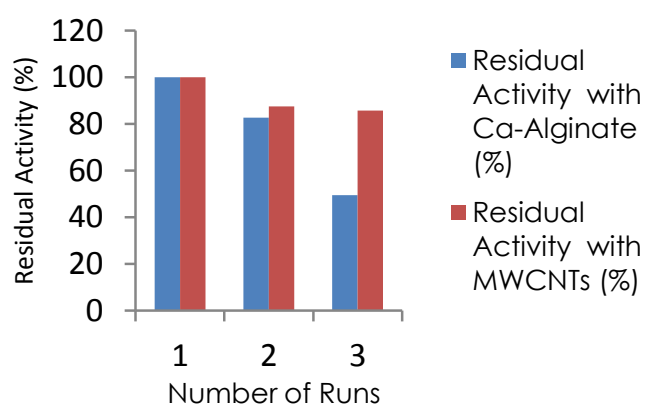

Figure 5 Reusability of immobilized enzyme on MWCNT and Ca-Alginate beads

\subsection{Kinetic Parameters of Immobilized Enzyme}

Enzyme activity vs. substrate concentration data were plotted using linearized Michaelis-Menten equation on Langmuir, Lineweaver-Burk and EadieHofstee plots [31]. The regression coefficient, $\mathrm{R}^{2}$ values for each method, and the corresponding Michaelis parameters obtained for $\beta$-glucosidase immobilized on MWCNT and Ca-alginate are shown in Tables 1 and 2, respectively.

Langmuir plot for linearized Michael-Menten equation gave the best fit to our kinetic data with $\mathrm{R}^{2}$ of more than $99.9 \%$ as shown in Figures 6 and 7 . Thus the true kinetic constants were obtained using the 
Langmuir plot. These were: $K_{m}$ and $V_{\max }$ as $0.8010 \mathrm{mM}$ and $1.3238 \mathrm{mM} /$ minute, respectively, for MWCNT; and $0.5237 \mathrm{mM}$ and $1.2401 \mathrm{mM} /$ minute, respectively, for Ca-alginate beads. Using Lineweaver-Burk plot, Su et al. [7] obtained kinetic constant, $\mathrm{K}_{\mathrm{m}}$ for immobilized $\beta$-glucosidase equal to $1.97 \mathrm{mmol} / \mathrm{L}$ which is more than twice as large as $K_{m}$ values in this study. This might be owing to stronger binding of enzyme due to cross-linking that resulted in lesser affinity of substrate to enzyme in [7] compared to only entrapment in our case.

Table 1 Summary of kinetic parameters for $\beta$ - glucosidase immobilized on MWCNT

\begin{tabular}{llll}
\hline Model & $\begin{array}{l}\boldsymbol{K}_{\boldsymbol{m}} \\
(\mathbf{m M})\end{array}$ & $\begin{array}{l}\boldsymbol{V}_{\max } \\
(\mathbf{m M} / \mathbf{m i n})\end{array}$ & $\mathbf{R}^{\mathbf{2}}$ \\
\hline Langmuir & 0.8010 & 1.3238 & 0.9996 \\
$\begin{array}{l}\text { Line-Weaver- } \\
\text { Burk }\end{array}$ & 0.4914 & 1.2977 & 0.8242 \\
Eadie-Hofstee & 0.6124 & 1.3100 & 0.8100 \\
\hline
\end{tabular}

Table 2 Summary of kinetic parameters for $\beta$ - glucosidase immobilized in Ca-alginate beads

\begin{tabular}{llll}
\hline Model & $\begin{array}{l}\boldsymbol{K}_{\boldsymbol{m}} \\
(\mathbf{m M})\end{array}$ & $\begin{array}{l}\boldsymbol{V}_{\max } \\
(\mathbf{m M} / \mathbf{m i n})\end{array}$ & $\mathbf{R}^{\mathbf{2}}$ \\
\hline $\begin{array}{l}\text { Langmuir } \\
\text { Line-Weaver- }\end{array}$ & 0.5237 & 1.2401 & 0.9995 \\
$\begin{array}{l}\text { Burk } \\
\text { Eadie-Hofstee }\end{array}$ & 0.2543 & 1.2188 & 0.6429 \\
\hline
\end{tabular}

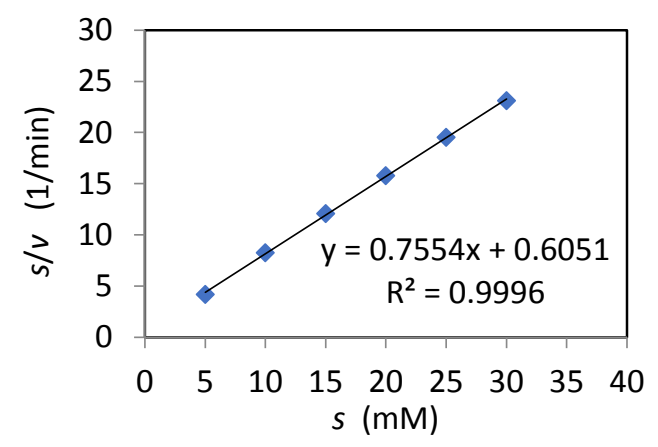

Figure 6 Langmuir Plot for immobilised enzyme on MWCNT

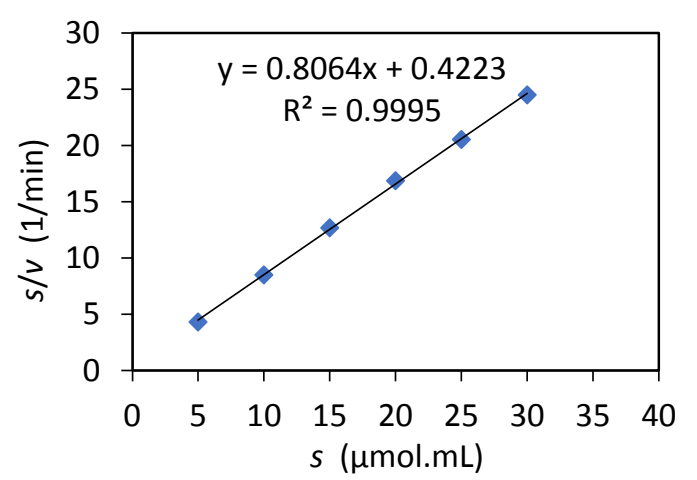

Figure 7 Langmuir Plot for immobilized enzyme on Caalginate beads
It should be noted that most researchers, in recent published literature, have reported kinetic constants obtained using Lineweaver-Burk plot (also known as double-reciprocal plot) apparently without testing other linearized plots for Michaelis-Menten equation $[1,5,7,8,28]$. However, Lineweaver-Burk plot is likely to incur significant round-off errors especially at small values of substrate concentration, $s$ and reaction rate, $v$ possibly due to reciprocal of small numbers $(1 / \mathrm{V}$ vs. $1 / \mathrm{s})$ involved in calculations of $K_{m}$ and $V_{\text {max }}$. On the other hand, Langmuir plot is likely to give more accurate results at small $s$ and $v$ values owing to $s$ in the numerator. More often than not, we have found that the Langmuir plot gives a much better fit than other linearized plots as is evident from the results presented here and also reported elsewhere [31].

The $V_{\max }$ for enzyme immobilized on MWCNT was found to be relatively higher than that of Caalginate. This could possibly be due to the higher resistance to substrate diffusion encountered in the Ca-alginate porous matrix. Also, the $K_{m}$ value for MWCNT is significantly higher than that of Caalginate, suggesting a decreased enzyme affinity for the substrate in the case of MWCNT as support material. This could be due to the fact that immobilization on functionalized MWCNT might have decreased the access of substrate to the enzyme active sites due to covalent bonding of the enzyme molecule with the functional groups on the MWCNT surface and, thus blocking the enzyme active sites [1, 5 , 7]. It is reported that using non-covalent approaches, enzymes can be less denatured upon immobilization and the intrinsic electronic structure and properties of MWCNT are preserved [10]. In terms of highest maximum reaction rate achieved in this study, functionalized MWCNT appears to be the better choice as support material compared to Caalginate beads.

\subsection{CONCLUSION}

Surface functionalized MWCNT likely leads to higher immobilization yield of $\beta$-glucosidase possibly due to preferential attachment of enzyme to functional groups formed at MWCNT surfaces. This is evident from FTIR spectra and SEM images. Maximum enzyme loading on MWCNT support was obtained for $4 \mathrm{~h}$ immobilization time and $17 \mathrm{mg} \mathrm{MWCNT/mg}$ enzyme. On the other hand, maximum enzyme loading for Ca-alginate support was observed at $2 \mathrm{~h}$ immobilization time and $3.5 \%(\mathrm{w} / \mathrm{v})$ sodium alginate solution for a constant mass (1 mg) of the enzyme. MWCNT as support material resulted in higher immobilization yield compared to Ca-alginate beads. Residual activity of biocatalysts at the third consecutive use was substantially higher for MWCNT support (85.5\%) than for Ca-alginate beads (49.3\%). This also indicates a more stable binding of enzyme to functionalized MWCNT on one hand, while substantial enzyme leakage from alginate beads 
over subsequent use. Finally, Langmuir plot gave an excellent fit to our kinetic data with regression coefficient over $99.9 \%$. The Michaelis constants, $K_{m}$ and $V_{\text {max }}$ for MWCNT immobilized $\beta$-glucosidase were higher than those of Ca-alginate beads indicating a higher rate of substrate conversion by MWCNT biocatalyst. A decrease in $K_{m}$ value for alginate beads compared to MWCNT may be due to increased affinity of enzyme for the substrate in alginate beads owing to physical adsorption of enzyme compared to covalent attachment in the case of functionalized MWCNT. However a decrease in $V_{\text {max }}$ value in alginate beads is possibly due to the increased resistance to diffusion of substrate to enzyme active sites inside the porous matrix compared to MWCNT. Thus all these findings favour MWCNT as a novel support for $\beta$-glucosidase immobilization with high stability and high substrate conversion, compared to Ca-alginate beads under the limit of the experimental protocol adopted in this study.

\section{Acknowledgement}

Part-time research assistance-ship to the second author (KYM) under the IIUM grant EDW B13-036-0921 is gratefully acknowledged.

\section{References}

[1] Ansari, S. A., Sattar, R., Chibber, S., and Khan, M. J. 2013. Enhanced Stability of Luyveromyces $\beta$ Galactosidase Immobilized on Glutaraldehyde Modified Multiwalled Carbon Nanotubes. Journal of Molecular Catalysis B: Enzymatic. 97: 258-263.

https://doi.org/10.1016/j.molcatb.2013.09.008

[2] Busto, M. D., Ortega, N., and Perez-Mateos, M. 1997. Effect of Immobilization on the Stability of Bacterial and Fungal $\beta$-d-glucosidase. Process Biochemistry. 32(5): 441449.

[3] Tan, H., Feng, W., and Ji, P. 2012. Lipase Immobilized on Magnetic Multi-walled Carbon Nanotubes. Bioresource Technology. 115: 172-176. https://doi.org/10.1016/S0032-9592(96)00104-5

[4] Tan, I. S., and Lee, K. T. 2015. Immobilization of $\beta$ glucosidase from Aspergillus Niger on K-carrageenan Hybrid Matrix and its Application on the Production of Reducing Sugar from Macroalgae Cellulosic Residue. Bioresource Technology. 184: 386-394. http://dx.doi.org/10.1016/j.biotech.2014.10.146.

[5] Abdulla, R., and Ravindra, P. 2013. Characterization of Cross Linked Burkholderia Cepacia Lipase in Alginate and $\mathrm{k}$-carrageenan Hybrid Matrix. Journal of the Taiwan Institute of Chemical Engineers. 44: 54555.http://dx.doi.org/10.1016/j.jtice.2013.01.003.

[6] Jung, Y. R, Shin, H. Y., Song, Y. S., Kim, S. B., and Kim, S. W. 2012. Enhancement of Immobilized Enzyme Activity by Pretreatment of $\beta$-glucosidase with Cellobiose and Glucose. Journal of Industrial and Engineering Chemistry. 18: 702-706. https://doi.org/10.1016/j.jiec.2011.11.133.

[7] Tumturk, H., Karaca, N., Demirel, G., and Sahin, F. 2007. Preparation and Application of $\operatorname{Poly}(n, n-$ dimethylacrylamide-co-acrylamide) and Poly(nisopropylacrylamide-co-acrylamide)/K-carrageenan
Hydrogels for Immobilization of Lipase. International Journal of Biological Macromolecules. 40: 281-285. https://doi.org/10.1016/j.ijbiomac.2006.07.004.

[8] Filiz Kara, F., Demirel, G., and Hayrettin, T. 2006. Immobilization of Urease by using Chitosan-alginate and Poly(acrylamide-co-acrylic acid)/k-carrageenan Supports. Bioprocess and Biosystems Engineering. 29: 207211.

[9] Datta, S., Christena, L. R., and Rajaram, Y. R. S. 2013. Enzyme Immobilization: An Overview on Techniques and Support Materials. Biotech. 3: 1-9.

[10] Feng, W. and Ji, P. 2011. Enzymes Immobilized on Carbon Nanotubes. Biotechnology Advances. 29: 889-895. https://doi.org/10.1016/j.biotechadv.2011.07.007.

[11] Sheldon, R. A. 2007. Enzyme Immobilization. Advanced Synthesis \& Catalysis. 349: 1289-1307.

[12] Li, L., Feng, W., and Pan, K. 2013. Immobilization of Lipase on Amino-cyclodextrin Functionalized Carbon Nanotubes for Enzymatic Catalysis at the Ionic Liquid-organic Solvent Interface. Colloids and Surfaces B: Biointerfaces. 102: 124129. https://doi.org/10.1016/j.colsurfb.2012.07.050.

[13] Mubarak, N. M., Wong, J. R., Tan, K. W., Sahu, J. N., Abdullah, E. C., Jayakumar, N. S., and Ganesan, P. 2014. Immobilization of Cellulose Enzyme on Functionalized Multiwall Carbon Nanotubes. Journal of Molecular Catalysis B: Enzymatic. 107: 124-131. https://doi.org/10.1016/j.molcatb.2014.06.002.

[14] Prlainovic, N. Z., Bezbradica, D. I., Rogan, J. R., Uskokovic, P. S., Mijin, D. Z., and Marinkovic, A. D. 2016. Surfacec Functionalization of Oxidized Multi-walled Carbon Nanotubes: Candida rugose Lipase Immobilization. Comptes Rendus Chimie. 19(3): 363-370. http://dx.doi.org/10.1016/j.crci.2015.10.008.

[15] Verma, M. L., Naebe, M., Barrow, C. J., and Puri, M. 2013. Enzyme Immobilization on Amino-functionalized MultiWalled Carbon Nanotubes: Structural and Biocatalytic Characterization. PLOS ONE. 8: 1-9.

[16] Won, K., Kim, S., Kim, K.-J., Park, H. W., and Moon, S.-J. 2005. Optimization of Lipase Entrapment in ca-alginate Gel Beads. Process Biochemistry. 40(6): 21 49-2154. https://doi.org/10.1016/j.procbio.2004.08.014.

[17] Gomez, J. M., Romero, M. D., and Fernandez, T. M. 2005. Immobilization of $\beta$-glucosidase on Carbon Nanotubes. Catalysis Letters. 101 (3-4): 275-278.

[18] Roy, S. K., Raha, S. K., Dey, S. K., and Chakrabarty, S. L. 1989. Immobilization of $\beta$-glucosidase from Myceliophthora thermophile D-14. Enzyme Enzyme and Microbial Technology. 11: 431-435.

[19] Betigeri, S. S., and Neau, S. H. 2002. Immobilization of Lipase using Hydrophilic Polymers in the Form of Hydrogel Beads. Biomaterials. 23: 3627-3636. https://doi.org/10.1016/S0142-9612(02)00095-9.

[20] Knezevic, Z., Bobic, S., Milutinovic, A., Obradovic, B., Mojovic, L., and Bugraski, B. 2002. Alginate-immobilized Lipase by Electrostatic Extrusion for the Purpose of Palm Oil Hydrolysis in Lecithin/isooctane System. Process Biochemistry. 38: 313-318.

[21] Keerti, A. K., Kumar, V., Dubey, A., and Verma, A. K. 2014. Kinetic Characterization and Effect of Immobilized Thermostable $\beta$-glucosidase in Alginate Gel Beads on Sugarcane Juice. ISRN Biochemistry. 2014: 178498. http://dx.doi.org/10.1155/2014/178498.

[22] Mfombep, P. M., Seno, Z. N., and Isikhuemhen, O. S. 2013. Enzymatic Activities and Kinetic Properties of $\beta$ glucosidase from Selected White Rot Fungi. Advances in Biological Chemistry. 3:198-207.

[23] Prlainovic, N. Z., Bezbradica, D. I., Knezevic-Jugovic, Z. D., Stevanovic, S. I., Avramov Ivic, M. L., Uskokovic, P. S., and Mijin, D. Z. 2013. Adsorption of Lipase from Candida Rugose on Multi Walled Carbon Nanotubes. Journal of Industrial and Engineering Chemistry. 19: 279-285.

[24] Zniszczol, A., Herman, A. P., Szymanska, K., MrowiecBialon, J., Walczak, K. Z., Jarzebski, A., and Boncel, S. 2016. Covalently Immobilized Lipase on Aminoalkyl-, Carboxy- 
and Hydroxyl-multi-wall Carbon Nanotubes in the Enantioselective Synthesis of Solketal Esters. Enzyme and Microbial Technology. 87-88: 61-69.

https://doi.org/10.1016/j.enzmictec.2016.02.015

[25] Dizge, N., Keskinler, B., and Tanriseven, A. 2008. Covalent Attachment of Microbial Lipase onto Microporous Styrene-divinylbenzene Copolymer by Means of Polyglutraldehyde. Colloids and Surfaces B: Biointerfaces. 66: 34-38.

[26] Ortega, N, Busto, M. D., and Perez-Mateos, M. 1998 Optimization of $\beta$-glucosidase Entrapment in Alginate and Polyacrylamide Gels. Bioresource Technology. 64: 105-111.

[27] Su, E., Xiaa, T., Gao, L., Dai, Q., and Zhang, Z. 2010. Immobilization of $\beta$-glucosidase and its Aroma-increasing Effect on Tea Beverage. Food and Bioproducts Processing. 88: 83-89.

[28] Coutinho, T. C., Rojas, M. J., Tardioli, P. W., Paris, E. C., and Farinas, C. S. 2018. Nanoimmobilization of $\beta$-glucosidase onto Hydroxyapatite. International Journal of Biological
Macromolecules.

119: doi:10.1016/j.jijbiomac.2018.08.042

1042-1051

[29] Han, J., Luo, P., Wang, Y., Wang, L., Li, C., Zhang, W., Dong, J., and Ni, L. 2018. The Development of Nanobiocatalysis via the Immobilization of Cellulase on Composite Magnetic Nanomaterial for Enhanced Loading Capacity and Catalytic Activity. International Journal of Biological Macromolecules. 119: 692-700 doi:10.1016/j.ijbiomac.2018.07.176.

[30] Maalim, K. Y. 2016. Optimization of $\beta$-glucosidase Enzyme Immobilisation on Ca-alginate and Carbon Nanotubes and the Evaluation of their Effectiveness Factors. Final Year Bachelor's Degree Project Report. International Islamic University Malaysia, Kuala Lumpur.

[31] Doran, P. M. 2013. Bioprocess Engineering Principles. 2nd Edition. Oxford: Academic Press. 